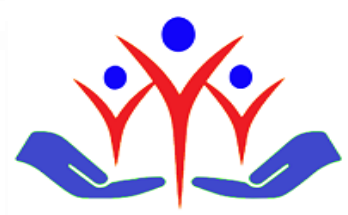

Family Practice and Palliative Care

doi $\underline{\text { https://doi.org/10.22391/fppc.753918 }}$

Research Article

\title{
Evaluation of patients receiving treatment at palliative care centers
}

\author{
Palyatif bakım merkezlerinde tedavi gören hastaların değerlendirilmesi
}

\author{
(D) Humeyra Aslaner ${ }^{\mathbf{a}}$ (iD) Ali Ramazan Benlib ${ }^{\mathbf{b}}$ Mebrure Beyza Gokcek ${ }^{\mathbf{c}}$, ${ }_{\text {Deniz Avcia }}$, Osman Baspinar $^{\mathbf{a}}$ \\ a Department of Family Medicine, Kayseri City Education and Research Hospital, Kayseri, Turkey \\ b Department of Family Medicine, School of Medicine, Karabuk University, Karabuk, Turkey \\ c Department of Family Medicine, Kayseri Provincial Directorate of Health, Kayseri, Turkey
}

\begin{abstract}
Introduction: Palliative care centers (PC centers) provide multidisciplinary care for patients with multiple comorbid conditions. This study aimed to assess and compare patients' diagnoses, length of hospital stays, and demographic data and coordination with home health care services.

Methods: This is a descriptive, cross-sectional and retrospective study. Patients who were hospitalized in PC centers of secondary and tertiary care hospitals between 01.08.2018 and 01.08.2018 were retrospectively assessed. Patients' demographic characteristics diagnoses of hospitalization, and length of hospital stays and centers where they received treatment were recorded.

Results: Median age of 830 patients included in the study was 79 (24-102). Out of 830 patients, $48.9 \%$ were male and $51.1 \%$ were female. Mean length of hospital stay was 14 days and median length was 8.7 (0.6-112) days. The three most common comorbid diseases followed up were malignancy $(21.8 \%)$, cerebrovascular disease $(15.2 \%)$ and malaise-fatigue-senility (10.7\%). The group with Alzheimer's disease was the oldest patient group. The group with nutritional deficiency-malnutrition was the patient group with the longest hospital stay ( $\mathrm{p}=0.030$ ). The number of patients who were hospitalized for cerebrovascular diseases was the highest in secondary care centers and the number of patients who were hospitalized for malignancy was the highest in tertiary care centers. Patients hospitalized in secondary PC center were older. The hospital stays were longer in tertiary PC center. Patients receiving treatment at a tertiary PC center had a significantly higher rate of mortality. The number of patients who were discharged was lower in the tertiary PC centers. Hospitalization to a secondary PC center through home care units was significantly higher.

Conclusion: In this study, the rate and diagnoses of hospitalization and length of hospital stays were different in secondary and tertiary PC centers. Our study has made an assessment about palliative care centers at various levels of health care and can be considered as prior knowledge for other studies.
\end{abstract}

Keywords: Palliative care, alzheimer disease, neoplasms, fatigue, cerebrovascular disorders, malnutrition

\section{$\ddot{\mathbf{O} z}$}

Giriş: Palyatif bakım merkezleri (PBM) çoklu komorbid durumlari bulunan hastalara multidisipliner bakım veren merkezlerdir. Bu çalışmamızda PBM'nde tedavi gören hastaların tanıları, yatış süreleri, demografik verileri ve evde sağlık hizmetleri ile koordinasyonunu değerlendirip karşılaştırmayı amaçladık.

Yöntem: Tanımlayıcı, kesitsel, retrospektif tipte bir çalışmadır. İkinci ve üçüncü basamak hastanelerin, PBM'de 01.08.2018 ile 01.03.2020 tarihleri arasında yatan hastalar retrospektif olarak değerlendirildi. Hastaların demografik özellikleri, yatış tanıları, yatış süreleri, tedavi gördügü merkezler kaydedildi.

Bulgular: Çalışmaya dahil edilen 830 hastanın yaş ortancası 79 (24-102) du. Hastaların \%48,9'u erkek, \%51,1'i kadın hastaydı. Yatış süresi ortalamas1 14, ortancas1 8,7 (0,6-112) gündü. En s1k takip edilen üç komorbid hastalık kanser $(\% 21,8)$, serebrovasküler hastalık $(\% 15,2)$ ve kırgınlık, yorgunluk-yaşlılık $(\% 10,7)$ idi. Alzheimer hastalığı grubu en yaşlı bakım alan hasta grubunu oluşturmaktaydı. Beslenme eksikliğimalnütrisyon en uzun süre yatan hasta grubuydu. İkinci basamak merkezde daha fazla kişi serebrovasküler hastalıklardan, üçüncü basamak PBM'de kanser hastalıklarından daha fazla kişi yatarak tedavi almıştı. İkinci basamak PBM'de yatan hastalar daha yaşlıdır. Üçüncü basamak PBM' de ise yatış süresi daha uzundur. Üçüncü basamak PBM'de tedavi alan hastaların exitus oranı daha yüksekti. Üçüncü basamak PBM'den taburcu olan hasta sayısı daha azdı. İkinci basamak PBM'ye evde sağlık birimi üzerinden yatış daha fazlaydı.

Sonuç: Bu çalışmada ikinci ve üçüncü Basamak PBM'leri arasında yatış oranları, tanıları ve süreleri farklılık göstermiştir. Çalışmamız çeşitli basamaklarda bulunan palyatif bakım merkezleri hakkında durum tespiti yapmış olup başka çalışmaların yapılması konusunda önbilgi niteliğinde değerlendirilebilir.

Anahtar kelimeler: Palyatif bakım, alzheimer hastalığı, malignite, kırgınlık, serebrovasküler hastalıklar, malnütrisyon

\begin{tabular}{|c|c|c|c|c|}
\hline Received & Accepted & Published Online & Corresponding Author & E-mail \\
\hline June 17, 2020 & December 21, 2020 & December 24, 2020 & Mebrure Beyaz Gokcek, MD & beyzaozgun@gmail.com \\
\hline Correspondence & \multicolumn{2}{|l|}{ Dr. Mebrure Beyaz Gökçek, Seyitgazi, Nuh Naci Yazgan Cd. No:2, 38030 Melikgazi/Kayseri } \\
\hline
\end{tabular}




\section{Introduction}

Palliative care, which is considered among human rights values, is a care approach that aims to reduce the pain and pain of patients and improve the quality of life[1]. Especially chronic diseases and the increase in the frequency of malignancy and rapid developments in treatment options increased the need for palliative care. Palliative care will become even more important due to the growing elderly population worldwide [2]. Palliative care requires a comprehensive assessment and multidisciplinary approach. It aims to remove physical, psychosocial and emotional symptoms of the patients with treatment in addition to supporting their family and friends and those who provide the care and relieving their grief $[3,4]$. There are differences in national palliative care policies in terms of performing this service. However, in general, palliative care may include a comprehensive medical practice such as home care, inpatient care in specific or conventional units in the hospital, daycare and outpatient care, and emergency care. All of these should focus on the changing needs and desires of patients and their relatives.

Palliative care has reached a good point in Turkey and the awareness rate among healthcare workers has increased. Palliative care centers have started to be established in inpatient health facilities within the scope of the "Directive About the Application Procedures and Principles of Palliative Care" which came into force in 2015. In these centers, patients with multiple chronic problems and end-stage cancer patients are followed and receive treatment [5].

Although the number of palliative care centers is increasing, they are still having difficulty in meeting the need. In addition, clinical experience of the personnel is not sufficient. It is important to reveal the condition of palliative care centers and assess the clinical profile of hospitalized patients. Palliative care centers serve at different levels of health care. These centers have some differences in terms of their operational processes [6(2)]. This study aimed to assess and compare coordination with home health care services and the diagnoses, lifetimes, and demographic data of the patients who received treatment in the Palliative Care Centers of secondary and tertiary care hospitals in Kayseri.

\section{Methods}

Secondary palliative care centers work in more coordination with home health services in Kayseri. Mostly patients who are admitted to the emergency department or outpatient clinics are hospitalized in tertiary PC centers because home health services in tertiary care have just been established and have less control in the field. Patients who were hospitalized at Kayseri State Hospital serving as secondary care hospital and Kayseri City Training and Research Hospital serving as tertiary care hospital between 01.08.2018 and 01.03.2020 were included in this descriptive, cross-sectional and retrospective study. Demographic characteristics, hospitalization, hospital stay, mortality, number of hospitalization from home health services or other clinics were recorded. Hospital stays durations stated in hours in the system were assessed in day scale.

\section{Statistical analysis}

SPSS 22.0 (SPSS Inc. Chicago, IL) program was used for statistical analysis. Descriptive statistics were given as percentage, mean \pm standard deviation (Mean $\pm \mathrm{SD}$ ) and median ( $\min -\max$ ) values. Student $\mathrm{T}$ test was used to compare normally distributed independent groups. Mann Whitney U test was used for non-normally distributed data. Chi square test was used to compare categorical data.

\section{Ethical approval}

The study was approved by the ethics committee of Kayseri City Training and Research Hospital (14.05.2020/73).

\section{Results}

A total of 830 patients who were hospitalized in PC centers between 01.08.2018 and 01.03.2020 were included in our study. The median age of 830 patients included in the study was 79 (24-102), 406 (48.9\%) of the patients were male and $424(51.1 \%)$ were female. Patients' mean length of hospital stays was 14 , and median length was 8.7 (0.6-112) days. The three most common comorbidities were malignancy in 181 patients (21.8\%), cerebrovascular disease in 126 patients (15.2\%) and malaise-fatigue-senility in 89 patients (10.7\%) (Table 1).

Table 1. Diagnoses of admission to PC centers, length of hospital stays and age parameters

\begin{tabular}{lllcc}
\hline Diagnosis & $\mathbf{n}$ & $\%$ & $\begin{array}{c}\text { Age } \\
\text { med (min-max) }\end{array}$ & $\begin{array}{c}\text { Length of hospital stay } \\
\text { med (min-max) }\end{array}$ \\
\hline Pain & 30 & 3.6 & $64(24-90)$ & $8.7(0.07-50.8)$ \\
Asthma-COPD & 69 & 8.3 & $79(31-93)$ & $6.3(0.0-57.7)$ \\
Malignancy & 181 & 21.8 & $67(27-100)$ & $9.8(0.00-112.1)$ \\
Urinary System Pathologies & 49 & 5.9 & $80(24-93)$ & $11.2(0.5-59.6)$ \\
Alzheimer's Disease & 83 & 10 & $86(52-99)$ & $8.4(0.6-77.9)$ \\
Wound-Infection & 36 & 4.3 & $82.5(31-95)$ & $5.7(0.0-30.3)$ \\
Other Neurological Diseases & 75 & 9 & $72(27-99)$ & $9.2(0.00-93.7)$ \\
Cerebrovascular Diseases & 126 & 15.2 & $82(47-98)$ & $7.4(0.00-73.2)$ \\
Nutritional Deficiency Sequels-GIS Diseases & 54 & 6.5 & $80.5(41-100)$ & $11.3(0.03-59.3)$ \\
Trauma & 3 & 4 & $79(38-86)$ & $8.3(1.3-11.3)$ \\
Hypertension-Diabetes Mellitus & 35 & 4.2 & $80(61-91)$ & $6.01(0.4-21.2)$ \\
Malaise-Fatigue-Senility & 89 & 10.7 & $81(40-102)$ & $10.4(0.00-110)$ \\
\hline
\end{tabular}

COPD: Chronic obstructive pulmonary disease, GIS: Gastrointestinal System 
When the relationship between the diagnosis and age of the patients was assessed, a significant difference was found between the diagnoses in terms of age ( $\mathrm{p}=0.012)$ (Table 1). Median ages were 86 (52-99) for Alzheimer's disease, 82 (47-98) cerebrovascular disease, and 82.5 (31-95) for wound- infection. Patients in the group of asthma, COPD, Alzheimer's disease, malaise-fatigue-senility, and hypertension-diabetes mellitus were older than the pain group $(\mathrm{p}=0.042, \mathrm{p}<0.001, \mathrm{p}<0.001, \mathrm{p}=0.009$ respectively). The patients in the Alzheimer's disease group were older than those in the malignancy and asthma-COPD group ( $<<0.001, \mathrm{p}=0.004$ respectively). Patients with asthma-COPD and urinary system pathologies were significantly older than those with malignancy $(\mathrm{p}<0.001)$.

When the relationship between diagnosis and hospitalization of patients was assessed a significant difference was found in terms of diagnosis and hospitalization ( $\mathrm{p}=0.012$ ) (Table 1). Considering the length of hospital stays, the group with nutritional deficiency-malnutrition had the longest hospital stay with $11.325(0.030-59.3)$ days. Malignancy patients' hospital stay was longer than that of hypertension-diabetes mellitus and woundinfection group ( $\mathrm{p}<0.001, \mathrm{p}=0.012$ respectively). Hospital stay of the groups with Alzheimer's disease was significantly longer than that of nutritional deficiency sequels-GIS diseases, cerebrovascular disease, urinary system pathologies and hypertension-diabetes mellitus groups $(\mathrm{p}<0.001, \mathrm{p}=0.006, \mathrm{p}=0.020, \mathrm{p}=0.006$ respectively). Hospital stay of malaise-fatigue-senility group was significantly longer than that of woundinfection group $(\mathrm{p}=0.012)$.

Considering the age ranges and length of hospital stays in the secondary and tertiary PC Centers, it was observed that the patients in the tertiary PC centers were younger and had longer hospital stay (Table 2).

Table 2. Length of hospital stays and age range in the secondary and tertiary PC centers

\begin{tabular}{lccc}
\hline & Secondary PC Center (n:445, 53.6\%) & Tertiary PC Center (n:385, 46.4\%) & $\boldsymbol{P}^{*}$ \\
\cline { 2 - 5 } Length of hospital stay (day) & $7.1(0.65-77.9)$ & $12.03(1-112.1)$ & $<0.001$ \\
Age (year) & $80(27-102)$ & $76(24-100)$ & $<0.001$ \\
\hline
\end{tabular}

*Mann Whitney U Test

When the number of patients hospitalized in both centers was assessed according to the diagnoses, it was observed that the number of those who received inpatient treatment for cerebrovascular disease was higher in secondary PC centers while the number of those who received inpatient treatment for malignancy was higher in tertiary PC Centers (Table 3). When the length of hospital stay was assessed according to the diagnoses, the nutritional deficiency-GIS diseases group was observed to have the longest hospital stay [13.265 (0.39-45.19)] in the secondary palliative care centers. On the other hand, the malaise-fatigue-senility had the longest hospital stay [13.85 (0-110.08)] in the tertiary palliative care centers group (Table 3). The oldest patient group who received treatment in both centers was the patient group diagnosed with Alzheimer's disease (Table 3).

Table 3. Comparison of patients in secondary and tertiary care centers according to their diagnoses

\begin{tabular}{|c|c|c|c|c|c|c|c|c|c|}
\hline \multirow[b]{2}{*}{ Diagnosis } & \multicolumn{3}{|c|}{ Secondary PC Center of Hospitals } & \multicolumn{3}{|c|}{ Tertiary PC Center of Hospitals } & \multirow[b]{2}{*}{$p 1$} & \multirow[b]{2}{*}{$p 2$} & \multirow[b]{2}{*}{$p 3$} \\
\hline & $\begin{array}{c}\text { Inpatient } \\
\text { n }(\%) \\
\end{array}$ & $\begin{array}{c}\text { Age } \\
\text { (median) }\end{array}$ & $\begin{array}{l}\text { Length of stay } \\
\text { (day) (median) }\end{array}$ & $\begin{array}{c}\text { Inpatient } \\
\text { n }(\%) \\
\end{array}$ & $\begin{array}{c}\text { Age } \\
\text { (median) }\end{array}$ & $\begin{array}{c}\text { Length of stay (day) } \\
\text { (median) }\end{array}$ & & & \\
\hline Pain & $8(0.018)$ & $59(56-77)$ & $1.975(0.62-7.39)$ & $22(0.057)$ & $64.5(24-86)$ & $11.63(0.07-50.82)$ & $<0.001$ & 0.027 & 0.185 \\
\hline $\begin{array}{l}\text { Alzheimer's } \\
\text { Disease }\end{array}$ & $51(0.115)$ & $82(61-96)$ & $7.3(0.02-28.65)$ & $18(0.047)$ & $86(73-95)$ & $12.87(1.15-45.85)$ & $<0.001$ & 0.250 & 0.527 \\
\hline $\begin{array}{l}\text { Asthma-COPD } \\
\text { Nutritional }\end{array}$ & $58(0.13)$ & $81(31-93)$ & $4.4(0.45-43.4)$ & $123(0.319)$ & $70(59-92)$ & $11.09(0-48.94)$ & $<0.001$ & 0.060 & 0.743 \\
\hline $\begin{array}{l}\text { Deficiency } \\
\text { Sequels-GIS } \\
\text { Diseases }\end{array}$ & $9(0.02)$ & $81(41-91)$ & $13.265(0.39-45.19)$ & $40(0.104)$ & $73(47-100)$ & $6.975(0.03-45.14)$ & $<0.001$ & 0.518 & 0.318 \\
\hline $\begin{array}{l}\text { Other Neurological } \\
\text { Diseases }\end{array}$ & $68(0.153)$ & $58(27-94)$ & $8.34(0-52.45)$ & $15(0.039)$ & $77(37-99)$ & $12.45(0.85-93.78)$ & $<0.001$ & 0.037 & 0.300 \\
\hline $\begin{array}{l}\text { Hypertension- } \\
\text { Diabetes Mellitus }\end{array}$ & $25(0.056)$ & $79.5(65-91)$ & $4.985(0.4-21.25)$ & $11(0.029)$ & $78(72-79)$ & $6.01(085-7.95)$ & 0.267 & 0.479 & 0.287 \\
\hline $\begin{array}{l}\text { Malaise-Fatigue- } \\
\text { Senility }\end{array}$ & $40(0.09)$ & $78(40-89)$ & $5.905(0.6-24.02)$ & $35(0.091)$ & $82(62-94)$ & $13.85(0-110.08)$ & 0.505 & 0.004 & 0.264 \\
\hline Malignancy & $79(0.178)$ & $70.5(33-91)$ & $6.7(0-50.3)$ & $47(0.122)$ & $65(27-100)$ & $10.93(0.08-112.12)$ & 0.011 & 0.226 & 0.077 \\
\hline $\begin{array}{l}\text { Cerebrovascular } \\
\text { Disease }\end{array}$ & $34(0.076)$ & $81(56-95)$ & $6.465(0-43.92)$ & $20(0.052)$ & $79(47-96)$ & $13.16(1.01-73.72)$ & 0.010 & 0.001 & 0.047 \\
\hline $\begin{array}{l}\text { Urinary System } \\
\text { Pathologies }\end{array}$ & $3(0.007)$ & $81(79-86)$ & $9.855(8.35-11.36)$ & $0(0)$ & $80(24)$ & $13.95(0.82-59.63)$ & $<0.001$ & 0.043 & 0.102 \\
\hline Wound-Infection & $32(0.072)$ & $76.9(31-95)$ & $5.98(2.56-21.14)$ & $3(0.008)$ & $74.9(57-95)$ & $15.1(0.35-23.12)$ & $<0.001$ & 0.028 & 0.194 \\
\hline
\end{tabular}

p1: Chi Square Test, p2 and p3 Mann Whitney U Test, COPD: Chronic obstructive pulmonary disease, GIS: Gastrointestinal System 
The mortality rate of the patients receiving treatment in this study was $29.3 \%(\mathrm{n}=244)$, the discharge rate was $58.4 \%(\mathrm{n}=485)$, and the rate of referral to intensive care was $12.3 \%(\mathrm{n}=101)$. The mortality rate of patients receiving treatment in the tertiary PC centers was $47.27 \%(\mathrm{n}=182)$, discharge rate was $40.51 \%(n=156)$, and the referral rate for intensive care was $12.2 \%(n=47)$. The mortality rate of patients receiving treatment in the secondary PC centers was $14 \%(\mathrm{n}=62)$, the discharge rate was $73.9 \%(\mathrm{n}=329)$, and the referral rate for intensive care was $12.1 \%(\mathrm{n}=54)$. The number of patients who were referred from home health care units and hospitalized in the secondary PC center was 155 (35\%) and the number of those who were referred from the emergency room-other clinics and hospitalized in the secondary PC center was 290 (65\%). Considering the rates of hospitalization in the tertiary PC centers, 77 (20\%) patients were referred from home health unit and $308(80 \%)$ were referred from the emergency room and other clinics.

\section{Discussion}

As in the whole world, the need for palliative care centers is increasing gradually due to the increasing elderly patient population in Turkey as well as increasing advanced chronic diseases [2]. In Turkey, the number of palliative care centers and clinical experience are still less than expected [5]. With this study, we presented the demographic characteristics, hospitalization diagnoses and length of hospital stays of patients admitted to palliative care centers in the secondary and tertiary care hospitals within 18 month and differences between the centers. In the study conducted by Yuruyen et al. in a palliative care center of a tertiary hospital, mean age of the patients was 71 and $45 \%$ of the patients were female while $41 \%$ of the patients were female and mean age was 70.6 in another similar study. The mean length of hospital stay in PC centers was 27.2 days in a study while it was $14.50 \pm 12.03$ days in another study in literature [7,8]. In our study, mean age of the patients was $74.5,51.1 \%$ were female, and the mean length of hospital was 14 days. Our results are similar to those in other studies in literature. We think patients at the age of 70 and above need care more in palliative care centers. The number of female population especially at the age of 65 and above is higher, which reveals that disability in these age groups is more in women than in men [9].

The three most common comorbid diseases in the PC centers are malnutrition (59\%), malignancy (44\%) and infection disease (33\%) (5). Benli et al. reported in their study that neurological disorders and malignancies including cerebrovascular events were in the first place in terms of the diagnosis of hospitalization in tertiary PC centers [8]. In our study, the rate of malignancy and cerebrovascular disease was higher, which is consistent with the findings in literature.

As far as we know the number of studies comparing hospitalization diagnoses, length of hospital stays and demographic data of inpatients in different PC centers is low [7]. The number of patients who are hospitalized for cerebrovascular diseases is the highest in secondary PC centers and the number of patients who are hospitalized for malignancy is the highest in tertiary PC centers. This may be because the number of patients who are referred from home health units to secondary PC centers is higher while the number of patients who are referred from oncology/hematology clinics to tertiary PC centers is higher. In home health care services, the number of patients followed up for cerebrovascular disease, Alzheimer's disease, hypertension and cardiovascular diseases is higher [10].

Patients hospitalized in tertiary PC centers are younger. In studies on cancer groups, mean age is decreasing in cancer patients compared to the other patients in PC centers [11,12]. Malignancy patients account for the largest part of the patients hospitalized in the tertiary palliative care centers, which may cause the mean age to be younger. While hospital stay of patients hospitalized for cerebrovascular diseases is the longest in palliative care centers hospital stay of patients hospitalized for cancer is shorter [5]. In our study, the second most common patients in tertiary PC centers were those receiving care for senility, which may have extended the length of hospital stays rather than patients with malignancy.

In the study by Yuruyen et al., the rate of patients discharged was 52\%, the rate of referral to intensive care was $15 \%$ and the mortality rate was $33 \%$ [5]. Akdogan et al. found in their study that mortality rate in the PC center of a tertiary care hospital was 43.0\%, referral to intensive care unit was $24.3 \%$, and the discharge rate was $32.8 \%$ [13]. Mortality rates and intensive care referral rates of the patients included in our study were found to be consistent with the findings in literature.

Mortality rate in tertiary PC centers is similar to that in literature, but it is higher than the rate in the secondary PC centers. This may be because the number of patients receiving care for end-stage malignancy is higher in tertiary PC centers. Oncological patients have the highest rate in tertiary PC centers because inpatient bed availability is more and there is an oncology clinic in these centers. Mostly the bed-bound patients are followed up in secondary care. This may be because home health care services have bed-bound patient profile and work in coordination with secondary care.

\section{Limitations}

This study was performed retrospectively and with document scanning method, which may be the limitation of our study.

\section{Conclusion}

In this study, the rate and diagnoses of hospitalization and length of hospital stays were different in secondary and tertiary PC centers. The rate of patients followed up for cerebrovascular diseases is higher in secondary care. This may be because they are similar to patient group followed up by home health care services. The rate of cancer patients is higher, hospital stay is longer and mortality rate is higher in tertiary care. This may because further examination, diagnosis and treatment are performed in tertiary care centers. Our study has made an assessment about palliative care centers at various levels of health care and can be considered as prior knowledge for other studies.

\section{Conflict of interest: None}




\begin{tabular}{|c|l|l|}
\hline \multicolumn{2}{|c|}{ Author Contributions } & \multicolumn{1}{c|}{ Author Initials } \\
\hline SCD & Study Conception and Design & HA, MBG, ARB \\
\hline AD & Acquisition of Data & HA, DA, MBG,OB \\
\hline AID & Analysis and Interpretation of Data & HA, ARB, MBG, \\
\hline DM & Drafting of Manuscript & MBG,DA,OB \\
\hline CR & Critical Revision & ARB, DA, OB \\
\hline
\end{tabular}

\section{Financial support: None}

\section{References}

1. Busolo D, Woodgate R. Palliative care experiences of adult cancer patients from ethnocultural groups: a qualitative systematic review protocol. JBI Database System Rev Implement Rep 2015;13(1):99-111. https://doi.org/10.11124/jbisrir-2015-1809

2. Voumard R, Rubli Truchard E, Benaroyo L, Borasio GD, Büla C, Jox RJ. Geriatric palliative care: a view of its concept, challenges and strategies. BMC Geriatr 2018;18(1):220. https://doi.org/10.1186/s12877-018-0914-0

3. Sepulveda C, Marlin A, Yoshida T, Ullrich A. Palliative care: The world health organization's global perspective. J Pain Symptom Manage 2002;24(2):91-6. https://doi.org/10.1016/s0885-3924(02)00440-2

4. WHO Definition of Palliative Care, World Health Organization, 2002. Available at: http://www.who.int/cancer/palliative/definition/en/ (Access Date: June 16, 2020)

5. Yuruyen M, Tevetoglu IO, Tekmen Y, Polat O, Arslan I, Okuturlar Y. [Prognostic factors and clinical features in palliative care patients] (in Turkish). Konuralp Med J 2018;10(1):74-80. https://doi.org/10.18521/ktd.368570

6. Uslu FS, Terzioglu F. [Palliative Care Education and Organization in the World and Turkey] (in Turkish). Cumhuriyet J Nurs 2015;4(2):8190.

7. Kahveci K, Dincer M, Doger C, Yarici AK. Traumatic brain injury and palliative care: A retrospective analysis of 49 patients receiving palliative care during 2013-2016 in Turkey. Neural Regen Res 2017;12:77-83. https://doi.org/10.4103/1673-5374.198987

8. Benli AR, Sunay D. [A model of collaboration between palliative care unit and home health care services: Karabuk] (in Turkish). Ankara Med J 2017;17(3):143-50. https://doi.org/10.17098/amj.33933

9. Regulation on home care services presentation. Presidential official journal of the republic of Turkey. Available at: https://www.resmigazete.gov.tr/eskiler/2005/03/20050310-5.htm (Access Date: June 15, 2020)

10. Onder T, Anuk T, Kahramanca S,Yildirim AC. [Evaluating sociodemographic and medical conditions of patients under home care service] (in Turkish). Dicle Med J 2015;42(3):342-5. https://doi.org/10.5798/diclemedj.0921.2015.03.0586

11. Ozalp G, Uysal N, Oguz G, Kocak N, Karaca S, Kadiogullari N. Identification of symptom clusters in cancer patients at palliative care clinic. Asia-Pacific J Oncol Nurs 2017;4(3):259-64. https://doi.org/10.4103/apjon.apjon_17_17

12. Uysal N, Senel G, Karaca S, Kadiogullari N, Kocak N, Oguz G. [Symptoms seen in inpatient palliative care and impact of palliative care unit on symptom control] (in Turkish). Agri 2015;27(2):104-10. https://doi.org/10.5505/agri.2015.26214

13. Akdogan D, Kahveci K. Evalution of geriatric infections in palliative care center. Turk Geriatr J 2018;21:507-14. https://doi.org/10.31086/tjgeri.2018.55 